\title{
Genotoxicity by Pahs In Shrimp (Litopenaeus Vannamei) and Its Impact on The Aquaculture of Two Coastal Ecosystems of The Gulf of California, Mexico
}

\author{
Guillermo Galindo Reyes
}

\begin{abstract}
During the last decades, aquaculture of several species have growth vertiginously around the world. In Mexico the shrimp aquaculture has been the most important. About 73-75 \% of shrimp hatcheries are in coastal ecosystems of the states of Sonora and Sinaloa, located along the Gulf of California. In this States there is not oil industry; however, several industries and other activities discharge petroleum derivatives (imprudently or accidentally) into coastal waters; as happens in Teacapan estuary and Huizache-Caimanero lagoon. The aim of this work was to quantify the levels of PAHs in water of these ecosystems, and to evaluate the genotoxic damage to shrimp, under laboratory conditions. Water samples were taken during rainy and dry months from both coastal systems, and then analyzed by Gas Chromatography (GC). Once known the PAHs concentrations, lots of seven juvenile shrimp were exposed to sub-lethal concentrations of Naphthalene, Phenanthrene, Chrysene, Fluorene, Anthracene, Pyrene, Fluoranthene, Benzo(b)fluoranthene and Benzo(a)pyrene during 21 days, since these were the most frequently PAHs found. At end of exposure period, genotoxicity was evaluated by Comet assay, and presence of micro-nucleus in shrimp haemocytes. Results demonstrated genotoxic damage by presence of comets, and micro-nucleus more frequently in exposed shrimps than controls. Also, a growth decrease was observed in exposed shrimps. These results, indicate potential risk for shrimp aquaculture in Sinaloa and human health, since shrimp is exported and consumed locally, and because in some cases, experimental PAHs concentrations were lower than concentrations of some PAHs found in water of Teacapan estuary and HuizacheCaimanero lagoon.
\end{abstract}

Index Terms - aquaculture, genotoxicity, PAHs pollution, shrimp.

\section{INTRODUCTION}

In Mexico as in other countries, the aquaculture activities have grown vertiginously during last decades. In 2018, the worldwide aquaculture production was estimated in 114.5 million tons, with a value of 263.6 billion of US dollars [1]. The cultivated shrimp in ponds under controlled conditions, is one of more important aquaculture species, with an estimate world production of 4.7 million tons in 2018 [2]. Although Mexico registered a severe decrease production in 2013, a growth of 180,000 tons is expected for 2021[2]. The same source reported that Mexico holds the sixth place in the world as shrimp producer after China, Vietnam,

Published on July 30, 2020

Guillermo Galindo Reyes, Universidad Tecnológica de Escuinapa, Mexico.

(e-mail: guillermo_galindo_reyes@hotmail.com)
Ecuador, India and Indonesia. In Mexico, 73-75 \% of shrimp hatcheries are located along coastal ecosystems of Sonora and Sinaloa States [3], which are located into the Gulf of California Fig.1. As currency income, the shrimp aquaculture is the most important in the country; this yielded approximately 778 million of US dollars, from which 56.3 $\%$ was produced in Sinaloa, during 2017 [3]. The same source report that for each produced ton of shrimp, $671 \mathrm{Kg}$ were produced in hatcheries, and $329 \mathrm{Kg}$ fished in estuaries, coastal lagoons and adjacent sea.

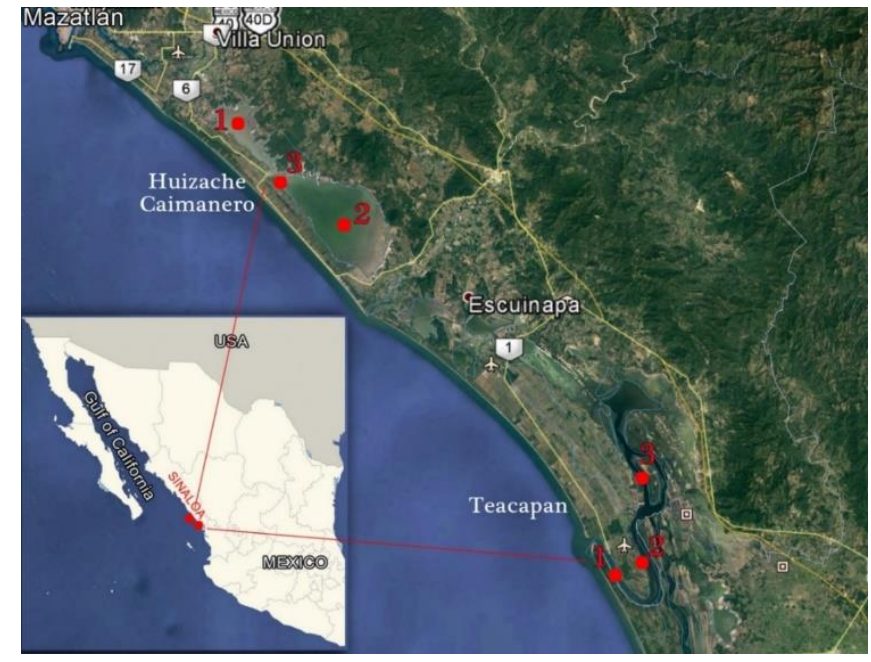

Fig. 1. In Mexico, 73-75\% of shrimp hatcheries are on the coast of Sinaloa and Sonora States, located along the Gulf of California. Three sampling sites were selected in the studied coastal systems (HuizacheCaimanero lagoon and Teacapan estuary) based on accessibility to reach the sites, and shrimp aquaculture and fishing activity.

On the other hand, although in the Gulf of California there are not oil industries, since all them are located in the Gulf of Mexico, previous studies have reported presence of Polycyclic Aromatic Hydrocarbons (PAHs) in coastal systems in the Sinaloa State [4], [5]; therefore, the presence of PAHs in this ecosystems becomes a problem for shrimp aquaculture, since all the hatcheries are located along the coastal zone, and take water to fill their shrimp ponds from these ecosystems; consequently, this becomes a risk for shrimp and human health. Therefore, the objective of this study was to evaluate the concentrations of PAHs in the waters of Teacapan estuary and Huizache-Caimanero lagoon; and then, to evaluate the genotoxic effect of these compounds in shrimps; because in last years, severe losses in the shrimp hatcheries, have been reported; probably due to intense traffic of fishing boats and other activities, such as shrimp freezing factories, agriculture equipment, shrimp hatcheries pumps and some industries, which use diesel, 
gasoline, and other petroleum products as energy source, and also by diverse chemicals, who wastes could be discharged to coastal ecosystems. Other authors have reported similar pollution problems in coastal systems [6], [7].

The PAHs are a group of compounds made up of several benzene and other aromatic rings linked together. They are produced by the incomplete combustion of fossil fuels (gasoline, diesel, fuel oil, coal, etc.), and other processes such as the burning of garbage, agricultural waste, etc. [8]. They could be also generated during natural processes such as forest fires and volcanic activity. The PAHs are widely distributed in almost all ecosystems of the planet. In the marine environment, the PAHs are found mainly in coastal areas [9], [5]. The entrances via of these pollutants to coastal ecosystems are diverse, such as continental runoff, atmospheric deposition, municipal and industrial effluents, and often by direct discharges [10], [11], [12]. The PAHs can enter to aquatic organisms by ingestion, respiration, filtration and dermal absorption; and due to their slow degradation process in the organisms, PAHs are commonly accumulated in tissues and muscles of aquatic organisms [13]. The acute toxicity in mice to light PAHs is moderate, ranged from 75 to 150 for Pyrene and Fluoranthene, while heavier PAHs have a higher toxicity; around 3 to 10 (mg/kg/day) for Benzo(a)pyrene and benzo(b)fluoranthene [14], [15]. The most critical effect of PAHs in mammals is due to their carcinogenic and genotoxic potential; for example, the Benzo (a) anthracene, Benzo (a) pyrene and Dibenzo (a, h) anthracene are considered potentially carcinogenic in humans [16], [17]. There are some works that assess the introduction routes of PAHs to coastal environments [18] and about the environmental degradation and its speciation process [19], [20]. However, the literature on PAHs contamination in the coasts of the Gulf of California, is scarce, and there has been little attention to toxicity of these pollutants on aquatic organisms.

\section{MAteriAl AND METHODS}

In order to know the water concentrations of PAHs, water samples were collected in three places of both ecosystems, during January, March, July and September, which correspond to the dry and rainy seasons respectively. The samples were collected using 4 L glass bottles. Previously, the bottles were rigorously washed with soap and water, and then, rinsed with distilled water and acetone. The collected samples were transported in coolers to laboratory where they were kept at $2-3{ }^{\circ} \mathrm{C}$ until processing. The PAHs in water were extracted using a liquid-liquid system. The extraction system consists of a balloon flask where $n$-hexane is vapored by a heat mantle; the n-hexane in vapor phase passes through the water sample, by a small bubbler located in bottom of extractor vessel. After, the n-hexane in the upper layer of the extractor with PAHs dissolved, drop by a glass tube arm connected to upper part of extractor and to balloon flask; the PAHs dissolved in n-hexane are adsorbed by an activated carbon trap, packed in a segment of descendent glass tube. The n-hexane without PAHs is reevaporated in the balloon flask and passed back through the water sample. The $n$-hexane recycling process was carried out during $4 \mathrm{~h}$. The PAHs absorbed by activated carbon were re-dissolved with fresh $n$-hexane. The extracts were clean-up passing them through packed columns $(3,3,3,4) \mathrm{g}$ of Silica-gel, Alumina, Florisil and anhydrous $\mathrm{Na}_{2} \mathrm{SO}_{4}$; then, extracts were concentrated until $2 \mathrm{ml}$, using a Rota vapor Buchi ${ }^{\circledR}$ R-210. The concentrates were carried out to dryness by a $\mathrm{N}_{2}$ gentle flow, and then re-dissolved in fresh $\mathrm{n}$-hexane. The PAHs analysis of clean extracts, were carried out by Gas Chromatography (GC), using an Agilent 6890® chromatograph (Palo Alto, CA), in splitless mode, fitted with a Flame Ionization Detector (FID), and a WCOT capillary column DB-5 (30 m x $0.25 \mathrm{~mm}$ OD) $5 \%$ phenyl methyl silicone. The operating conditions were as follows: an initial temperature of $60{ }^{\circ} \mathrm{C}$ during $3 \mathrm{~min}$, a ramp of $8{ }^{\circ} \mathrm{C} / \mathrm{min}$ until $320{ }^{\circ} \mathrm{C}$ keeping this temperature by $4 \mathrm{~min}$. The Injection and detector temperature were $250{ }^{\circ} \mathrm{C}$ and $330{ }^{\circ} \mathrm{C}$ respectively. Nitrogen (purity $\geq 99.7 \%$ ) was used as carrier gas at a constant flow rate of $2.5 \mathrm{ml} / \mathrm{min}$, and constant pressure (15 psi) during all run. Hydrogen was used as fuel gas with a flow rate of $40 \mathrm{ml} / \mathrm{min}$ and dry air as oxidant gas, with a flow rate of $450 \mathrm{ml} / \mathrm{min}$. The identification of PAHs congener was carried out comparing the retention time (RT) peaks in the samples chromatograms vs. the RT peaks of reference standard chromatogram of PAHs; corresponding to 16 parent PAHs priority [21]. The congener quantification was performed by the peak/area normalization method. The identification and quantification procedure was carrying out by Agilent ChemStation ${ }^{\circledR}$ software, installed in a computer attached to chromatograph. The reference standard was purchased in Sigma-Aldrich de Mexico, and other items were supplied by Agilent Technologies of Mexico (Mexico City).

During last years, several methods have been utilized to evaluate genotoxic damage in diverse aquatic species; however, the comet assay method for detecting DNA strand breaks, and the micronucleus count, as an index of chromosomal damage are the most used and validated methods. Groups of seven healthy juveniles shrimp (6.5-7.5 g each) were distributed in $20 \mathrm{~L}$ aquariums. The salinity was adjusted to 26-27 PSU (Practical Salinity Unit), adding filtered fresh water to filtered seawater. The water temperature of aquariums oscillates from $27-28{ }^{\circ} \mathrm{C}$, during experimentation time. Constant aeration was supplied to aquariums from an air blower. The shrimps were fed two times per day (5-7\% total shrimp weight) with commercial food (camaronina) supplied by Purina ${ }^{\circledR}$ of Mexico. The aquariums water was changed three times a week. Every time water was changed, $3 \mathrm{ml}$ of each experimental PAHs dissolved in acetone were added to aquariums. To determine the sublethal concentration of PAHs, several concentrations were assayed, until zero shrimp mortality was obtained. So, experimental concentrations of each PAHs in aquariums water, were the following: Pyrene $(1.3 \mu \mathrm{g} / \mathrm{l})$, Phenanthrene (3.3 $\mu \mathrm{g} / \mathrm{l})$, Naphthalene $(2.6 \mu \mathrm{g} / \mathrm{l})$, Chrysene $(1.6 \mu \mathrm{g} / \mathrm{l})$, Anthracene $(4.2 \mu \mathrm{g} / \mathrm{l})$, Fluorene $(12.5 \mu \mathrm{g} / \mathrm{l})$, Fluoranthene (5.2 $\mu \mathrm{g} / \mathrm{l})$, Benzo (b) fluoranthene (3.5 $\mu \mathrm{g} / \mathrm{l})$ and Benzo(a)pyrene $(1.5 \mu \mathrm{g} / \mathrm{l})$. As control, just $3 \mathrm{ml}$ of acetone was added to aquarium water. At the end of exposure time (21 days), 5 shrimps from each aquarium were measured and weighed; then accord to the procedure of [22] with some modifications, around $50 \mu \mathrm{l}$ haemolymph was 
extracted from each one shrimp, using a $0.5 \mathrm{ml}$ microsyringe, previously impregnated with a $5 \%$ EDTA solution as anticoagulant; after, $25 \mu \mathrm{l}$ haemolymph of each shrimp was spread on slides covered with a thin layer of Agarose MMT (medium melting temperature), and a second Agarose layer LMT (low melting temperature) was added to slides. After solidification, the slides were Immersed in Alkaline Unwinding Solution (200 mM NaOH, 1 mM EDTA) pH>13 during $60 \mathrm{~min}$ at $4{ }^{\circ} \mathrm{C}$ in the dark. Subsequently, the slides were placed in a horizontal electrophoresis chamber, and then covered with a $\mathrm{pH} \geq 8$ electrophoresis buffer $(10 \mathrm{mM}$ Tris, $1 \mathrm{mM}$ EDTA) and an electric strength of $300 \mathrm{~mA}$ and $25 \mathrm{~V}$ was applied using an electrophoresis power source BIORAD ${ }^{\circledR}$ FB-300 by $15 \mathrm{~min}$. The slides were taken off from electrophoresis tray, immersed in distilled water for $5 \mathrm{~min}$, and then in 70\% ethanol during 5-6 min, air dried and stained with $(0.001 \mu \mathrm{g} / \mathrm{ml})$ ethidium bromide (EB) by $30 \mathrm{~min}$ at room temperature in the dark. All the reagents were purchased in Sigma-Aldrich ${ }^{\circledR}$ de Mexico. Mexico City. Slides were rinsed in distilled water to discard excess of $\mathrm{EB}$ and dried at room temperature. In order to assess the genotoxic damaged by PAHs to shrimp haemocytes, the slides were observed by fluorescence microscopy at 496 $\mathrm{nm} / 522 \mathrm{~nm}$ for maximum excitation/emission, using a Leitz Laborlux S Fluorescence Microscope coupled to a digital camera Leica DFC-490 of 8 Mega Pixels, and a Dell monitor. The comet assay parameters tail length (TL), tail intensity (TI) or percentage of DNA in tail, and tail moment (TM) understood as tail length multiplied by the DNA fraction in the tail, were assessed using the software (Comet Assay IV®) supplied by Instem Co. Staffordshire, UK. Also, the amount of micronucleus in shrimp haemocytes were quantified by counting them in several microscopic fields, after an Eosin staining of haemocytes smears. Once finalized the genetic tests, the growth of exposed shrimp was estimated, by quantifying the weight increase of shrimp at end of exposure time.

\section{A. Statistical analyses}

All laboratory experiments and water analysis were performed by triplicate. The statistical parameter Mean and Standard Deviation (SD) of water samples, and growth experiment were determined by Excel of Microsoft Office 2010. The TL $(\mu \mathrm{m}), \mathrm{TM}$ and TI $(\%)$ parameters are reported as the Mean and SD of each PAHs used in genotoxic experiments. Analysis of variance (ANOVA) and NewmanKeuls tests, were used to determine significant differences between experimental PAHs and control, using a GraphPad Prism software. A significance was defined as $\mathrm{p} \leq 0.05$.

\section{Results AND Discussion}

\section{A. PAHs in water from ecosystems studied}

From the 16 priority PAHs stablished by [21] only 9 were found in water samples of both studied ecosystems. Their mean value concentrations in $\mu \mathrm{g} / 1$, are presented in Table I. As can be observed, Chrysene was the most frequent congener found with $79.2 \%$, and also at higher concentration, followed by Phenanthrene with $62.5 \%$ and Fluorene with $50 \%$. The others congener ranged from 45.8 to $25 \%$, and at lower concentrations than studied ecosystems. On the other hand, the higher concentrations were registered during rainy season.

Although concentrations of PAHs found in the studied ecosystems were lower than values reported by US coastal water [13] and coastal systems of other countries [20], in some cases the values were similar or higher than concentration used in the aquariums of the experimental assays; such as sub-lethal concentrations of Chrysene and Pyrene.

On the other hand, other authors, reported that PAHs are characterized by their hydrophobic properties, which allow them be adsorbed with suspended particulate matter and finally deposited in the sediment, which constitutes a PAHs reservoir; therefore, sediments become an important source of pollutants and can be a significant risk to aquatic organisms [23]. Also, there is a dynamic PAHs transfer between water and sediments; consequently, compounds adsorbed in sediments such as PAHs, becomes easily available to benthic organisms such as shrimp, crabs, clams, etc. [24].

\section{B. Genotoxicity and chromosomal damage}

The results of comet assay parameters are shown in Table II. For practical purposes, from all the samples processed, only the results of 22 samples, randomly selected are presented; otherwise, the amount of data in tables would be too large. As can see, the values presented indicate that PAHs genotoxicity to shrimp, is evident. There is not a clear correlation between parameter values of comet assay, and exposure concentrations of PAHs in aquarium water, presented as (Sample Code) in Table 2. This can be due that shrimp in laboratory experiments, were exposed at sublethal concentrations, i.e., the experiments objective, was not to know genotoxicity vs. PAHs concentrations, such that has been, in other works [22]. However, the DNA damage (strand breaks) was similar or lower than values reported by other authors, where crustaceous or other estuarine invertebrates, were exposure to some PAHs [25], [26], [27].

The results of the micronucleus frequency (index of chromosomal damage) of shrimp haemocytes are shown in Table III. The data demonstrate that PAHs are causing chromosomal damage in shrimp exposed to these pollutants, since the micronucleus frequently was increased. Therefore, results shown in Table II and Table III, indicate environmental impact by human activities such as boat's transit, accidental fuel spilling and other activities, which spill petroleum derivate in coastal ecosystems studied in this work. On the other hand, results demonstrate that juvenile shrimps (Litopenaeus vannamei), can be used as bioindicator of aquatic pollution; and the comet assay and micronucleus frequency, as powerful tools for the assessment of DNA genotoxicity, and chromosomal damage to shrimp haemocytes by PAHs. 
TABLE I: CONCENTRATION IN ( $\mu \mathrm{G} / \mathrm{L})$ OF PAHS IN WATER SAMPLES OF STUDIED COASTAL SYSTEMS. ABBREVIATIONS: NA: NAPHTHALENE; FLU: FLUORENE; Phe: Phenanthrene; Ant: Anthracene; Fluo: Fluoranthen; Pyr: Pyrene; Chry: Chrysene; B(B)F: Benzo(B)Fluoranthen; B(A)P:

\begin{tabular}{|c|c|c|c|c|c|c|c|c|c|}
\hline $\begin{array}{c}\text { Sampling } \\
\text { data }\end{array}$ & $\mathbf{N a}$ & Flu & Phe & Ant & Fluo & Pyr & Chry & $\mathbf{B}(\mathbf{a}) \mathbf{P}$ & $\mathbf{B}(\mathbf{b}) \mathbf{F}$ \\
\hline $\begin{array}{c}\text { H-C.1/Jan- } \\
2019\end{array}$ & ND & ND & ND & ND & ND & ND & $0.17 \pm 0.014$ & ND & ND \\
\hline $\begin{array}{c}\text { H-C.2/Jan- } \\
2019\end{array}$ & ND & ND & $0.041 \pm 0.005$ & ND & ND & ND & ND & ND & ND \\
\hline $\begin{array}{c}\text { H-C.3/Jan- } \\
2019\end{array}$ & $0.038 \pm 0.004$ & $0.031 \pm 0.003$ & $0.029 \pm 0.0022$ & ND & $0.023 \pm 0.0021$ & ND & $0.245 \pm 0.023$ & $0.019 \pm 0.0015$ & ND \\
\hline $\begin{array}{l}\text { Tea.1/Jan- } \\
2019\end{array}$ & ND & ND & ND & $0.031 \pm 0.009$ & ND & ND & ND & ND & ND \\
\hline $\begin{array}{c}\text { Tea.2/Jan- } \\
2019\end{array}$ & $0.033 \pm 0.008$ & $0.022 \pm 0.008$ & ND & ND & ND & ND & $0.314 \pm 0.049$ & ND & ND \\
\hline $\begin{array}{c}\text { Tea.3/Jan- } \\
2019\end{array}$ & ND & ND & $0.042 \pm 0.009$ & ND & ND & ND & ND & ND & ND \\
\hline $\begin{array}{l}\text { H-C1/ } \\
. \text { Mar-2019 }\end{array}$ & ND & ND & ND & $0.028 \pm 0.004$ & ND & ND & $0.59 \pm 0.12$ & $0.021 \pm 0-0017$ & ND \\
\hline $\begin{array}{l}\text { H-C.2/ } \\
\text { Mar-2019 }\end{array}$ & ND & $0.031 \pm 0.007$ & $0.029 \pm 0.003$ & ND & ND & ND & $0.93 \pm 0.087$ & ND & ND \\
\hline $\begin{array}{l}\text { H-C.3/ } \\
\text { Mar-2019 }\end{array}$ & $0.037 \pm 0.007$ & ND & $0.037 \pm 0.004$ & ND & $0.028 \pm 0.004$ & $0.025 \pm 0.002$ & $1.65 \pm 0.24$ & $0.018 \pm 0.0015$ & ND \\
\hline $\begin{array}{c}\text { Tea.1/Mar- } \\
2019\end{array}$ & ND & ND & ND & $0.035 \pm 0.003$ & ND & ND & ND & ND & ND \\
\hline $\begin{array}{c}\text { Tea.2/Mar- } \\
2019\end{array}$ & $0.027 \pm 0.006$ & ND & ND & ND & ND & ND & $2.34 \pm 0.32$ & ND & ND \\
\hline $\begin{array}{c}\text { Tea.3/Mar- } \\
2019\end{array}$ & ND & $0.037 \pm 0.008$ & ND & ND & ND & ND & $2.72 \pm 0.15$ & ND & $0.036 \pm 0.005$ \\
\hline $\begin{array}{c}\text { H-C.1/Jul- } \\
2019\end{array}$ & ND & $0.065 \pm 0.005$ & $0.061 \pm 0.007$ & $0.063 \pm 0.009$ & ND & $0.051 \pm 0.004$ & $6.74 \pm 0.62$ & $0.043 \pm 0.004$ & ND \\
\hline $\begin{array}{c}\text { H-C.2/Jul- } \\
2019\end{array}$ & ND & $0.068 \pm 0.009$ & ND & ND & ND & $0.035 \pm 0.004$ & $5.53 \pm 0.68$ & ND & ND \\
\hline $\begin{array}{c}\text { H-C.3/Jul- } \\
2019\end{array}$ & $0.67 \pm 0.15$ & ND & $0.132 \pm 0.058$ & ND & $0.066 \pm 0.008$ & $0.064 \pm 0-008$ & $10.45 \pm 1.02$ & $0.047 \pm 0.007$ & $0.058 \pm 0.005$ \\
\hline $\begin{array}{c}\text { Tea.1/Jul- } \\
2019 \\
\end{array}$ & $0.818 \pm 0.089$ & ND & $0.135 \pm 0.048$ & ND & ND & $0.122 \pm 0.095$ & $6.87 \pm 0.92$ & $0.051 \pm 0.006$ & ND \\
\hline $\begin{array}{c}\text { Tea.2/Jul- } \\
2019\end{array}$ & ND & $0.151 \pm 0.012$ & $0.119 \pm 0.09$ & $0.059 \pm=0.009$ & $0.091 \pm 0.099$ & $0.088 \pm 0.006$ & $16.14 \pm 1.54$ & ND & ND \\
\hline $\begin{array}{c}\text { Tea.3/Jul- } \\
2019\end{array}$ & $0.79 \pm 0.067$ & $0.179 \pm 0.021$ & $0.127 \pm 0.041$ & ND & ND & $0.127 \pm 0.011$ & $4.42 \pm 0.42$ & ND & $0.062 \pm 0.012$ \\
\hline $\begin{array}{l}\text { H-C.1/ } \\
\text { Sep-2019 }\end{array}$ & $0.66 \pm 0.057$ & $0.137 \pm 0.017$ & $0.125 \pm 0.012$ & $0.083 \pm 0.018$ & $0.131 \pm 0.011$ & ND & $10.59 \pm 0.49$ & $0.073 \pm 0.008$ & \\
\hline $\begin{array}{l}\text { H-C.2/ } \\
\text { Sep-2019 }\end{array}$ & ND & ND & $0.132 \pm 0.03$ & ND & ND & $1.42 \pm 0.16$ & $7.93 \pm 0.77$ & ND & $0.078 \pm 0.072$ \\
\hline $\begin{array}{l}\text { H-C.3/ } \\
\text { Sep-2019 }\end{array}$ & $0.75 \pm 0.069$ & $0.147 \pm 0.015$ & ND & $0.088 \pm=0.009$ & ND & $1.25 \pm 0.32$ & $9.65 \pm 0.89$ & $0.064 \pm 0.007$ & $0.068 \pm 0.011$ \\
\hline $\begin{array}{c}\text { Tea.1/Sep- } \\
2019\end{array}$ & ND & $0.165 \pm 0.016$ & $0.171 \pm 0.034$ & $0.135 \pm 0.019$ & $0.098 \pm 0.009$ & ND & ND & $0.073 \pm 0.007$ & ND \\
\hline $\begin{array}{c}\text { Tea.2/Sep- } \\
2019\end{array}$ & $0.75 \pm 0.068$ & ND & $0.158 \pm 0.016$ & $0.108 \pm 0.061$ & ND & $1.67 \pm 0.31$ & $15.34 \pm 1.42$ & $0.098 \pm 0.014$ & $0.089 \pm 0.012$ \\
\hline $\begin{array}{c}\text { Tea.3/Sep- } \\
2019\end{array}$ & $0.74 \pm 0.071$ & $0.162 \pm 0.018$ & $0.131 \pm 0.015$ & $0.122 \pm 0.057$ & ND & $1.49 \pm 0.26$ & $8.72 \pm 0.74$ & $0.068 \pm 0.005$ & ND \\
\hline
\end{tabular}

In the following figures, are shown the photographs by fluorescence microscopy of haemocytes cells of shrimps exposed to sub-lethal concentrations of Chrysene $(1.6 \mu \mathrm{g} / \mathrm{l})$, Pyrene $(1.3 \mu \mathrm{g} / \mathrm{l})$, Phenanthrene (3.3 $\mu \mathrm{g} / \mathrm{l})$, Naphthalene (2.6 $\mu \mathrm{g} / \mathrm{l})$,) Fluorene $(12.5 \mu \mathrm{g} / \mathrm{l})$, Anthracene $(4.2 \mu \mathrm{g} / \mathrm{l})$, Fluoranthene $(5.2 \mu \mathrm{g} / \mathrm{l})$, Benzo(b)fluoranthen $(3.5 \mu \mathrm{g} / \mathrm{l})$, Benzo(a)pyrene (1.5 $\mu \mathrm{g} / \mathrm{l})$ and control ( $3 \mathrm{ml})$ of acetone. As can be seen the comets in haemocytes were present in all shrimp exposure to PAHs, except in control.

The comets of haemocytes cells in above photographs (Figs 2 to 10) indicate that PAHs are genotoxic substances to shrimp even at low concentration; however, is necessary to consider that in the natural habitat, surely there are other xenobiotic compounds which could cause damage to DNA, mutagenicity and other toxicological alterations; therefore, laboratory experiments have a relevant value, but cannot be considered absolute. Other authors agree with this premise, since they consider that it is important to be careful with risk measures, because it is necessary to understand how the biota behaves in its totality, which implies a considerable different between laboratory results using model organisms, with the real conditions in their habitat [28].

Regarding the growth of exposed shrimp, a decrease in weight of all shrimp exposed to PAHs was detected, Fig. 12. As can be seen, the greatest decrease in weight correspond to shrimps exposed to Chrysene, whereas the smallest to Anthracene. This can be due to shrimp under toxic stress has a higher energy consumption to keep their vital functions; therefore, the energy available to growth becomes reduced; also, due to some features of this pollutants, since once the PAHs has been absorbed into organs and tissues of shrimp, they are distributed and accumulated, mainly in lipophilic tissues, and then, can be bio-transformed in other compounds by oxy-reduction reactions catalyzed by cytochrome P450, mixed function oxygenases, NADPHcytochrome, as well by conjugation reactions catalyzed by 
glutathione-S-transferase, sulfotransferase, epoxide hydrolase, and other transferase enzyme, increasing its water solubility [29]. The products of all these reactions can generate compounds with higher toxicological activity, causing genetic damages to aquatic organism, particularly to benthonic such as shrimp, since in bottoms of aquatic systems, all these reactions are more fast due to the benthic organisms are in intimal contact with the bottom. Other authors arrive to similar conclusions [30].

TABLE II: TAIL INTENSITY, TAIL LENGTH AND TAIL MOMENT IN HAEMOCYTES CELLS OF SHRIMP EXPOSED TO SUBSETAL PAHS CONCENTRATIONS IN LABORATORY EXPERIMENTS.

\begin{tabular}{ccccc}
\hline Sample & $\begin{array}{c}\text { Tail intensity } \\
\text { (\% of DNA } \\
\text { in in tail) } \\
\text { Mean } \pm \text { SD }\end{array}$ & $\begin{array}{c}\text { Tail length } \\
\text { Mean } \pm \text { SD }\end{array}$ & $\begin{array}{c}\text { Tail oment } \\
\text { Mean } \pm \text { SD }\end{array}$ & PAH congener \\
& & & \\
\hline CICON & $8.0 \pm 1.52$ & $24.44 \pm 1.02$ & $0.94 \pm 1.58$ & Naphthalene \\
C2CON & $10.0 \pm 2.23$ & $25.99 \pm 1.20$ & $1.55 \pm 0.56$ & Fluorene \\
C3CON & $16.0 \pm 23.40$ & $16.32 \pm 1.22$ & $1.44 \pm 1.02$ & Anthracene \\
C2MON & $5.0 \pm 1.44$ & $19.56 \pm 1.78$ & $0.91 \pm 1.3$ & Chrysene \\
C6PO1 & $12.0 \pm 1.31$ & $21.41 \pm 1.08$ & $0.94 \pm 0.64$ & Pyrene \\
C2PO1 & $6.0 \pm 1.38$ & $18.99 \pm 1.88$ & $1.58 \pm 0.77$ & Naphthalene \\
C4PO1 & $10.0 \pm 1.23$ & $15.99 \pm 1.20$ & $1.44 \pm 1.88$ & Phenanthrene \\
C3PO1 & $16.0 \pm 1.66$ & $19.33 \pm 0.93$ & $1.71 \pm 1.65$ & Fluorene \\
C1MON & $12.0 \pm 2.1$ & $25.44 \pm 1.10$ & $1.25 \pm 1.55$ & Naphthalene \\
C3MON & $18.0 \pm 1.77$ & $16.89 \pm 1.23$ & $1.86 \pm 2.65$ & Benzo(a)pyrene \\
C4MON & $15.0 \pm 0.97$ & $22.63 \pm 2.28$ & $0.77 \pm 1.02$ & Anthracene \\
C5MON & $18.0 \pm 1.12$ & $24.44 \pm 1.02$ & $1.06 \pm 0.71$ & Chrysene \\
C7CON & $18.0 \pm 1.02$ & $15.14 \pm 1.02$ & $0.99 \pm 0.44$ & Fluorene \\
C6MON & $16.32 \pm 0.92$ & $18.40 \pm 1.02$ & $1.09 \pm 1.21$ & Chrysene \\
C7MON & $10.0 \pm 1.25$ & $21.99 \pm 1.20$ & $1.33 \pm 0.70$ & Phenanthrene \\
C1PO1 & $14.44 \pm 1.02$ & $26.32 \pm 1.22$ & $1.69 \pm 1.02$ & Pyrene \\
C4CON & $16.32 \pm 1.22$ & $19.11 \pm 1.78$ & $0.91 \pm 1.31$ & Pyrene \\
C5CON & $19.56 \pm 1.78$ & $51.41 \pm 0.98$ & $1.86 \pm 1.64$ & Chrysene \\
C6CON & $15.0 \pm 1.07$ & $52.63 \pm 1.30$ & $1.77 \pm 0.22$ & Phenanthrene \\
C7CON & $10.0 \pm 2.00$ & $17.79 \pm 1.20$ & $1.64 \pm 8.68 *$ & Naphthalene \\
C7POI & $10.0 \pm 1.03$ & $15.99 \pm 1.20$ & $1.44 \pm 0.88 *$ & Anthracene \\
C5POI & $16.32 \pm 1.22$ & 16.971 .78 & $0.81 \pm 1.33$ & Benzo(a)pyrene \\
\hline$* N u m b e r$ & $0 f h a m 09 y t u s$ & quantified was $\leq 1000$. & \\
& & &
\end{tabular}

$*$ Number of haemocytus quantified was $\leq 1000$.

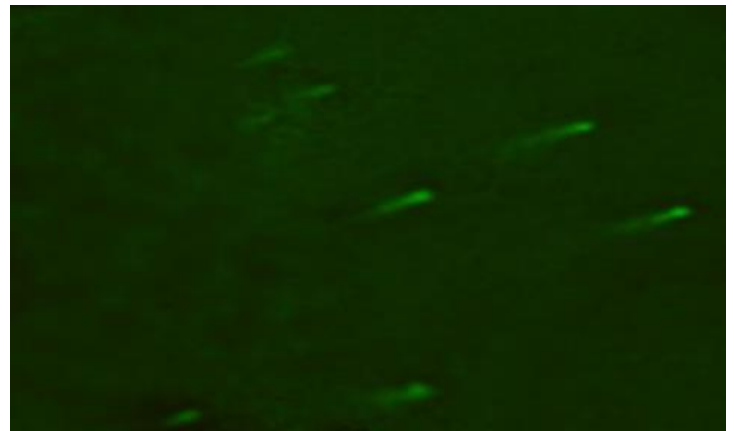

Fig 2. Nucleus of haemocytes cells of shrimp exposed to Chrysene, after the comet assay procedure, stained with $0.001 \mu \mathrm{g} / \mathrm{ml}$ ethidium bromide, and observed at $40 \mathrm{X}$ in a fluorescence microscope.

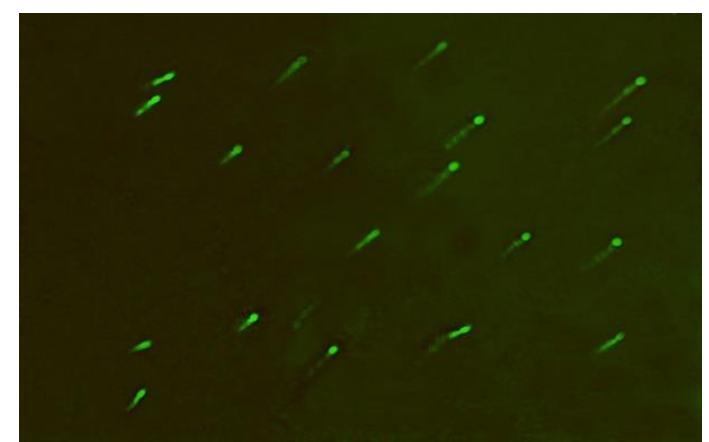

Fig 4. Nucleus of haemocytes cells of shrimp exposed to Phenanthrene, after the comet assay procedure, stained with $0.001 \mu \mathrm{g} / \mathrm{ml}$ ethidium bromide, and observed at $40 \mathrm{X}$ in a fluorescence microscope.
TABLE III: MICRONUCLEUS FREQUENCY OF HAEMOCYTES CELLS OF SHRIMP EXPOSED TO EXPERIMENTAL PAHS

\begin{tabular}{ccc}
\hline Sample Code & $\begin{array}{c}\text { Micronucleus } \\
\text { frequency }\end{array}$ & PAH congener \\
CICON & 1.0 & Naphthalene \\
C2CON & 2.0 & Fluorene \\
C3CON & 1.0 & Anthracene \\
C2MON & 1.0 & Chrysene \\
C6PO1 & 2.0 & Pyrene \\
C2PO1 & 1.0 & Naphthalene \\
C4PO1 & 1.0 & Phenanthrene \\
C3PO1 & 2.0 & Fluorene \\
C1MON & 1.0 & Naphthalene \\
C3MON & 1.0 & Benzo(a)pyrene \\
C4MON & 2.0 & Anthracene \\
C5MON & 1.0 & Chrysene \\
C7CON & $1.0^{*}$ & Fluorene \\
C6MON & 2.0 & Chrysene \\
C7MON & $1.0^{*}$ & Phenanthrene \\
C1PO1 & 3.0 & Pyrene \\
C4CON & 1.0 & Pyrene \\
C5CON & 2.0 & Chrysene \\
C6CON & $1.0^{*}$ & Phenanthrene \\
C7CON & 2.0 & Naphthalene \\
C7POI & 3.0 & Anthracene \\
C5POI & 2.0 & Benzo(a)pyrene \\
\hline
\end{tabular}

* Micronucleus Frequency quantified in haemocytus was $\leq 1000$. 


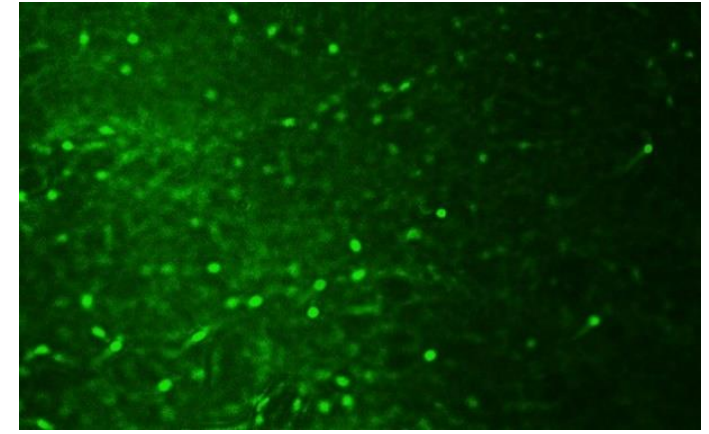

Fig 6. Nucleus of hemocytes cells of shrimp exposed to Fluorene, after the comet assay procedure, stained with $0.001 \mu \mathrm{g} / \mathrm{ml}$ ethidium bromide, and observed at $40 \mathrm{X}$ in a fluorescence microscope.

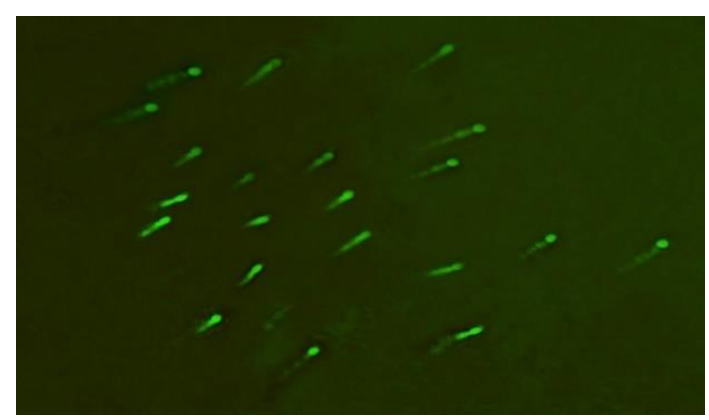

Fig 8. Nucleus of hemocytes cells of shrimp exposed to Fluoranthen, after the comet assay procedure, stained with $0.001 \mu \mathrm{g} / \mathrm{ml}$ ethidium bromide, and observed at $40 \mathrm{X}$ in a fluorescence microscope.

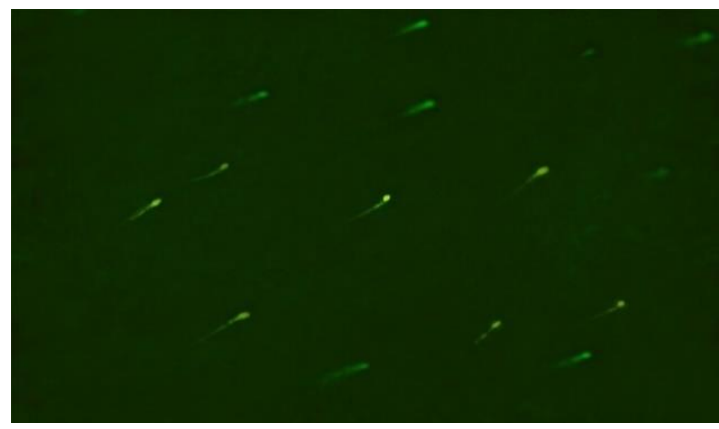

Fig 10. Nucleus of hemocytes cells of shrimp exposed to Benzo(a)pyrene, after the comet assay procedure, stained with $0.001 \mu \mathrm{g} / \mathrm{ml}$ ethidium bromide, and observed at $40 \mathrm{X}$ in a fluorescence microscope.

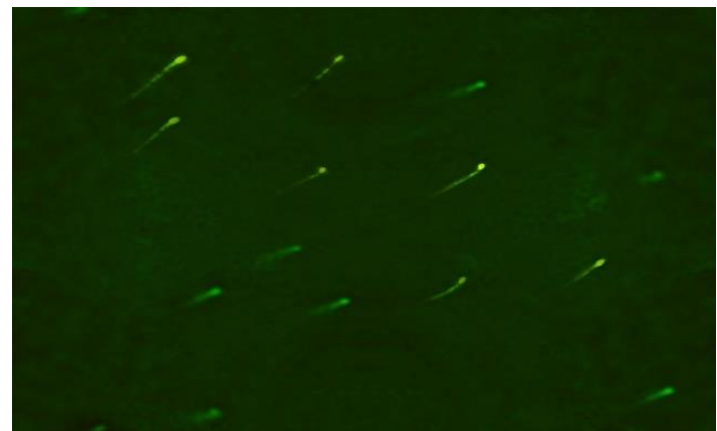

Fig 7. Nucleus of hemocytes cells of shrimp exposed to Anthracene, after the comet assay procedure, stained with $0.001 \mu \mathrm{g} / \mathrm{ml}$ ethidium bromide, and observed at $40 \mathrm{X}$ in a fluorescence microscope.

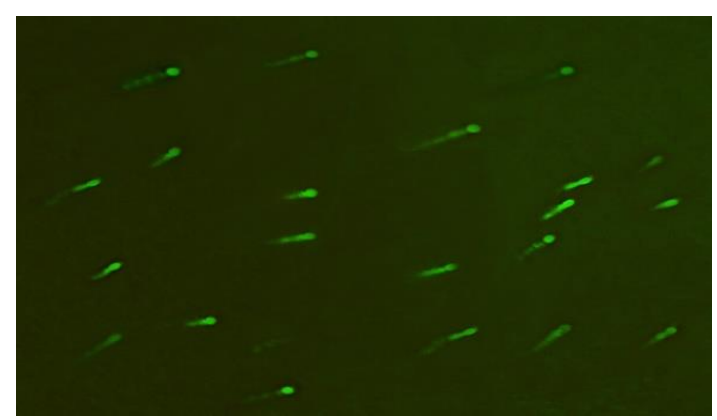

Fig 9. Nucleus of hemocytes cells of shrimp exposed to

Benzo(b)fluoranthen, after the comet assay procedure, stained with 0.001 $\mu \mathrm{g} / \mathrm{ml}$ ethidium bromide, and observed at $40 \mathrm{X}$ in a fluorescence microscope.

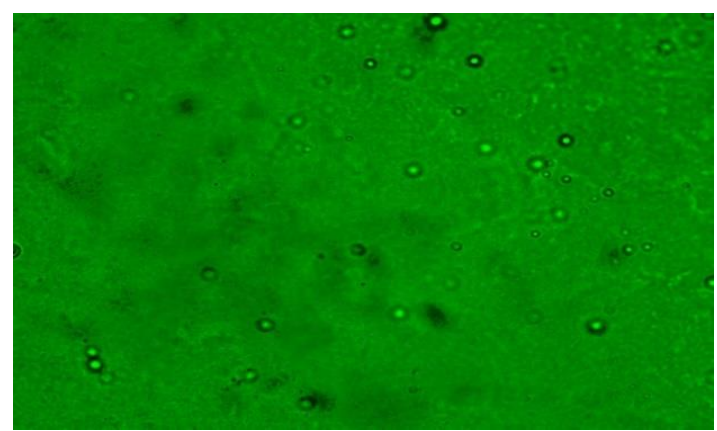

Fig 11. Nucleus of hemocytes cells of shrimp exposed to $3 \mathrm{ml}$ of acetone (control), after the comet assay procedure, stained with $0.001 \mu \mathrm{g} / \mathrm{ml}$ ethidium bromide, and observed at $40 \mathrm{X}$ in a fluorescence microscope.

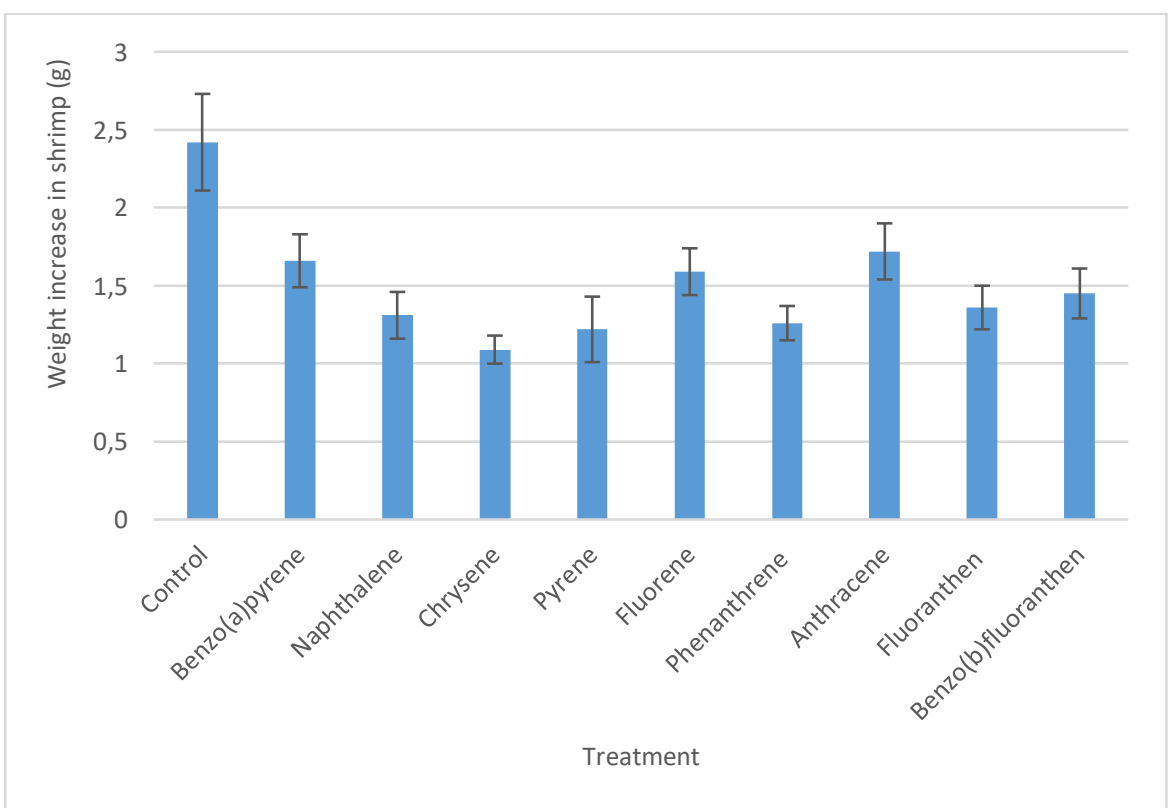

Fig. 12. Weight Increase in shrimp exposed to PAHs during 3 weeks. As can be seen the Chrysene was the congener that caused the lowest growth in shrimp. 


\section{CONCLUSION}

From PAHs concentration in water of coastal ecosystems studied, it is possible to conclude that they are relatively low compared to values reported for some coastal ecosystems of the US and other countries. However, these concentrations are sufficient to cause genotoxic damage to shrimp and possible infectious diseases; and also, a decrease in its growth, generating considerable losses in shrimp aquaculture. Furthermore, since these contaminants can bioaccumulate in the tissues of many aquatic organisms, the HAPs pollution becomes a risk to human health by consuming these seafood. Consequently, to reduce the amount of PAHs and decrease shrimp aquaculture losses; Production methods, currently used in agriculture and also in shrimp aquaculture, should be changed to more sustainable methods.

\section{ACKNOWLEDGMENT}

The author acknowledges the efforts of all students who contributed to success of this study; also, to the Dean of the Technological University of Escuinapa for their support to carrying out this work, and to Guiseppe R. Galindo for the English grammar review.

\section{REFERENCES}

[1] FAO. The state of world Fisheries and Aquaculture, in 2020 Interactive story. http://www.fao.org/state-of-fisheries-aquaculture.

[2] GOAL. Global shrimp production review 2019. https://www.aquaculturealliance.org/advocate/goal-2019-globalshrimp-production-review/.

[3] CONAPESCA Comisión Nacional de Acuacultura y Pesca. Anuario Estadístico de Acuacultura y Pesca. 2017. Gobierno de Mexico. Mexico

City https://www.conapesca.gob.mx/work/sites/cona/dgppe/2017/ANUA RIO_ESTADISTICO_2017.pdf

[4] Galindo Reyes G. Contaminación por Hidrocarburos Poliaromáticos en el Estero de Urías, Mazatlán, Sinaloa y sus Efectos en Camarones Revista Industria Acuícola. 2007; 3, 8-14 https://scholar.google.com.mx/scholar?hl=es\&as_sdt=0\%2C5\&q=G + Reyes+-

$+\% \mathrm{E} 2 \% 80 \% \mathrm{~A} 6+.+$ Universidad+Aut $\% \mathrm{C} 3 \% \mathrm{~B} 3$ noma+de+Sinaloa.+F acultad+de+\%E2\%80\%A6\%2C+2006\&btnG=

[5] Foday J M, Alegria H A, Galindo R J, Hoare A. Levels of PAHs in the waters, sediments, and shrimps of Estero de Urias; an estuary in Mexico, and their toxicological effects. 2012: 687034 Scientific World Journal. https://doi.org/10.1100/2012/687034.

[6] Ren X, Pan L, Wang L. Toxic effects upon exposure to benzo[a]pyrene in juvenile white shrimp Litopenaeus vannamei. Environmental Toxicology and Pharmacology. 2015; 39 (1) 194 207.https://doi.org/10.1016/j.etap.2014.08.006

[7] AI C, Xiaojuan W, Shaojing L, Guizhong W, Qiongwu L. Effects of Heavy Metal and Pollutants on the Non-special Immunity of the Shrimp and Crab. Marine Science Bulletin. 2008; 10 (1) 54-63.

[8] Uhler A and Emsbo-Mattingly S. Environmental Stability of PAH Source Indices in Pyrogenic Tars. Bull Environ Contam Toxicol. 2006; 76, 689-696. https://doi.org/10.1007/s00128-006-0975-1.

[9] Mostafa A R, Wade T L, Sweet S T, et al. Distribution and characteristics of polycyclic aromatic hydrocarbons (PAHs) in sediments of Hadhramout coastal area, Gulf of Aden, Yemen. Journal of Marine Systems. 2009; 78 (1) 1-8 https://doi.org/10.1016/j.jmarsys.2009.02.002.

[10] Eisler, R. Eisler's Encyclopedia of Environmentally Hazardous Priority Chemicals. Firs Edition.Pbls. by Elsevier. 2007. 651-669 pp. The Netherlands. Linacre House, Oxford OX28DP, UK.

[11] Hahladakis J, Smaragdaki E, Vasilaki G, Gidarakos E. Use of Sediment Quality Guidelines and pollution indicators for the assessment of heavy metal and PAH contamination in Greek surficial sea and lake sediments. Environ Monit Assess. 2013; 185:2843-2853. https://doi.org/10.1021/es021083h.

[12] Yuan X, Yang X, Zhang A, Ma X, Gao H, Na G, Zong H, Lui G, Sun Y. Distribution, potential sources and ecological risks of two persistent organic pollutants in the intertidal sediment at the Shuangtaizi Estuary, Bohai Sea of China. Marine Pollution Bulletin. 2017; 114 (1) 419-427. https://doi.org/10.1016/j.marpolbul.2016.09.058

[13] ATSDR Agency for Toxic Substances and Disease Registry. Toxic Substances Portal Polycyclic Aromatic Hydrocarbons (PAHs). 1996. 4770 Buford Hwy NE Atlanta, GA 30341. USA https://www.atsdr.cdc.gov/toxprofiles/tp69-c5.pdf.

[14] FAO/WHO, Safety evaluation of certain contaminants in food. World Health Organization, Geneva, Switzerland. 2006. 769 pp ISBN 924160554 (WHO), ISBN 92-5 105426-6 (FAO).

[15] The Danish Environmental Protection Agency. Polyaromatic Hydrocarbons (PAH). Evaluation of health hazards and estimation of a quality criterion. 2013. Strandgade 291401 Copenhagen K Denmark. ISBN 978-87-93026-78-0. www.mst.dk/english.

[16] Falcó G, Domingo J L, Llobet J M, Teixidó A, Casas C, Müller L. Polycyclic aromatic hydrocarbons in foods: human exposure through the dietary in Catalonia, Spain. 2003.. J. Food. Protect; 66, 23252331. https//doi.org/10.4315/0362-028x-66.12.2325.

[17] Rengarajan T, Rajendran P, Nandakumar N, Lokeshkumar B, RajendraneI P, Nishigaki I. Exposure to polycyclic aromatic hydrocarbons with special focus on cancer. Asian Pacific Journal of Tropical Biomedicine. 2015; 5 (3) 182-189. https://doi.org/10.1016/S2221-1691(15)30003-4.

[18] Menzie, C A, Hoeppner S S, Cura, J.J. et al. Urban and suburban storm water runoff as a source of polycyclic aromatic hydrocarbons (PAHs) to Massachusetts estuarine and coastal environments Estuaries 2002; 25, 165-176. https://doi.org/10.1007/BF02691305.

[19] Kammanna U. Akchab F, Budzinskic H, Burgeotb T, Gubbinse M .J, Langa T, Menachc $\mathrm{K}$ et al. PAH metabolites in fish bile: From the Seine estuary to Iceland. Marine Environmental Research. 2017; 124, 41-45. https://doi.org/10.1016/j.marenvres.2016.02.014.

[20] Adeniji A O, Okoh O O and Okoh A I. Levels of Polycyclic Aromatic Hydrocarbons in the Water and Sediment of Buffalo River Estuary, South Africa and Their Health Risk Assessment. Arch Environ Contam Toxicol. 2019; 76 (4) 657-669. https://doi.org/.1007/s00244-019-00617-w.

[21] US EPA. United States Environmental Protection Agency. PAH priority. 2010. list Fed. Regist.

[22] Rodríguez-Romero M I, Gómez-Arroyo S, Villalobos-Pietrini R, Martínez-Valenzuela $\mathrm{C}$, et al. Evaluation of 8-hydroxy-2' deoxyguanosine (8-OHdG) adduct levels and DNA strand breaks in human peripheral blood lymphocytes exposed in vitro to polycyclic aromatic hydrocarbons with or without animal metabolic activation. Toxicology Mechanisms and Methods, 2012; 22(3): 170-1 https://doi.org/10.3109/15376516.2011.623330.

[23] Merhaby D, Net S, Halwani J, Ouddane B. Organic pollution in surficial sediments of Tripoli harbour, Lebanon. Marine Pollution $\begin{array}{llll}\text { Bulletin. } & 2015 ; & 93 & (1-2)\end{array}$ https://doi.org/10.1016/j.marpolbul.2015.01.004.

[24] Nakata H, Sakai Y, Miyawaki T Takemura A. Bioaccumulation and Toxic Potencies of Polychlorinated Biphenyls and Polycyclic Aromatic Hydrocarbons in Tidal Flat and Coastal Ecosystems of the Ariake Sea, Japan. Environmental science \& Technology, 2003; 37 (16) 3513-3521. https://doi.org/10.1021/es021083h.

[25] Kuzmick D M, Mitchelmore C L, Hopkins W A, Rowe C L. Effects of Coal Combustion Residues on Survival, Antioxidant Potential, and Genotoxicity Resulting From Full-Lifecycle Exposure of Grass Shrimp (Palaemonetes Pugio Holthius) Sci Total Environ. 2007; 373 (1) 420-30. https://doi.org/10.1016/j.scitotenv.2006.11.009.

[26] Siu S Y M, Lam P K S, Martin M, Caldwell C W, Richardson J B. The use of selected genotoxicity assays in green-lipped mussels (Perna viridis): a validation study in Hong Kong coastal waters Marine pollution Bulletin. 2008; 57, 479-492. https://doi.org/10.1016/j.marpolbul.2008.03.006.

[27] da Silva-Rocha J A, Botelho T M, Hasue M F, Rocha-Passos M J , Vignardi P C, Ngan V P, Gomes V. Genotoxicity of shallow waters near the Brazilian Antarctic station "Commandant Ferraz" (eacf), admiralty bay, king George island, Antarctica. Brazilian Journal of Oceanography. 2015; 63, 1. https://doi.org/10.1590/S1679 87592015080906301.

[28] Martins M and Costa M P. The comet assay in Environmental Risk Assessment of marine pollutants: applications, assets and handicaps of surveying genotoxicity in non-model organisms. Mutagenesis 2015; 30 (1) 89-106. https://doi.org/10.1093/mutage/geu037. 
[29] Lechon M J V, Lahoz A, Gombau L, Castell J V, Donato M T. In Vitro Evaluation of Potential Hepatotoxicity Induced by Drugs. Curr Pharm Design. 2010; 16 (17) 1963-1977.

[30] Frohlich A, Andre L C, Moura D J. Genotoxicity and Cyotoxicity Evaluation Applied to Environmental Health, Research of Polycyclic Aromatic Hydrocarbons. Int J Sci Res Environ Sci Toxicol. 2018 3(2) $1-13$.

https://symbiosisonlinepublishing.com/toxicology/toxicologyenvironmental-science20.php. 